\title{
"Prospective" Application of Changes in Community Property Control--Rule of Property or Constitutional Necessity?
}

\author{
Barbara N. Armstrong*
}

"THE DECISIONS that existing statutes changing the rights of husband and wife in community property can have no retroactive application have become a rule of property in this state and should not now be overruled. It is my opinion, however, that the constitutional theory on which they are based is unsound.... (footnote) That theory has not become a rule of property and should not invalidate future legislation in this field intended by the legislature to operate retroactively." This statement was made by a member of the supreme court of our state in rendering a special concurring opinion in a community property case handed down in 1944. The unain opinion in this case held that the 1923 statute which grants the wife testamentary disposition of one-half of the community property did not apply, and, constitutionally, could not apply to property accumulated after 1923 as a rent, issue or profit of community which had existed prior to that date. While agreeing with the conclusion that the 1923 statute did not extend to such rents, issues and profits, ${ }^{2}$ the concurring opinion, rested this conclusion on a long usage basis and rejected as

*Professor of Law, University of California; A.B., J.D., Ph.D., University of California.

1 Justice Traynor in Boyd v. Oser (1944) 23 Cal. (2d) 613, 623, 145 P. (2d) 312, 318. The previous law review comment in 27 CALIF. L. REv. 49, cited in Justice Traynor's concurring opinion, persuasively argues the unsoundness of this constitutional doctrine. The amplification of argument, which this article involves, has seemed useful because of its great importance and also, as this is a memorial issue of the Review, hecause of Dean McMurray's strong conviction of its importance.

2 This conclusion of the court logically flowed from the previous opinion of McKay v. Lauriston (1928) $204 \mathrm{Cal}$. 557, 269 Pac. 519, which had denied the application (and the constitutional propriety of the application) of the wife's testamentary power to community property acquired prior to the efiective date of the 1923 statute.

Ohviously if such community property is to be completely free from interference through testamentary disposition of the wife, its profits and issues should he hikewise free. One of the prerequisites of property-one of the important sticks in that bundle of legal privileges which the legal concept of property comprises-is the right to use it for the purpose of deriving income and thus to add to the corpus originally held. 
fallacious the constitutional theory which had caused the original "prospective" interpretation of the 1923 statute.

Thus, for the first time ${ }^{3}$ from our highest bench, a voice has been raised in protest against the continued acceptance of a constitutional theory which, ever since the historic first Spreckels case, not only has colored our community property law to date, but also stands as an obstacle to efficient future revision of our community property system.

Just what is this "prospective application" rule? It is, briefly, that each of the legislative changes which have cut down the husband's inter vivos control of community property ${ }^{4}$ had no application to community property which was either already in the hands of the spouses, ${ }^{5}$ or which came into being at a later date as a result of the rents, issues and profits of such property.

In consequence, the marital property rule which applies at any one time to identical types of property in the hands of existing married couples is not one invariable rule, but one of a series of rules; which one of the series depends upon when the property or the corpus from which it originally derived, came into the hands of the spouses. The "tracing back" process, in the case of marriages of long duration, is often a tortuous process. If it can be carried through, however, the community property rule which was in effect at that original date will be the rule today. ${ }^{6}$

To illustrate, let us imagine three married couples living today, in the fall of 1945 , in the city of Oakland. The Abbotts are a very old couple, the Barretts are middle aged, and the Cabots are in their early thirties. In the case of each couple, aside from household furnishings and personal paraphernalia, the total family accumulations comprise

3 Infra note 55 .

4 It is not debated that succession rules are, under our concept of property, at the grace of the state and no "deprivation of property" is worked by a change in such rules made after acquisition of property.

5 This, of course, includes property which is later acquired in exchange for such property or as a result of its investment.

${ }^{6}$ It can be said with certainty that this is an accurate statement with reference to all the changes in control that the legislature so far has seen fit to make. Each of these changes, however, antedated the 1927 statute (CAI. Crv. CoDE \$162.5) which states that the interests of the husband and wife in community property are present, existing and equal.

We have had no interpretation of the "prospective application" doctrine in respect to such legislative changes made after the 1927 statute as the legislature in this period has not made any substantial change in our marital property law. 
income-bearing realty bought in 1940 and recorded in the husband's name. Neither husband nor wife had any property when they married, and neither has inherited property or has been given any through inter vivos gift or legacy. In each case, the property in question is a product of the earnings of one or both of the spouses after marriage, together with the rents, issues and profits of such earnings.

While it is clear that the property of each of these three couples is commumity property, and this fact is understood, there is some disagreement as to the exact right of control which the respective spouses can exercise in respect to the property. Each of the couples consults an attorney with the request that he advise them as to their rights and duties. We will assume that exact and accurate counsel follows in due course. What in each instance will that be?

1. The Abbotts.

After appropriate research, counsel discovers that Mr. Abbott has paid for the real property in question with the proceeds of the sale of a ranch which he had acquired in 1930; that the ranch had been purchased by funds realized by the sale of a large block of stock in the American Telephone and Telegraph Co., some of which had been purchased between 1920 and 1930 with funds derived from the dividends paid on the original stock, which had been purchased by Mr. Abbott in 1910; that the original block of Telephone and Telegraph stock acquired in 1910 had been bought with cash realized from the sale of a well-chosen downtown San Francisco lot which Mr. Abbott had purchased in 1890.

Counsel, therefore, informs the Abbotts that Mr. Abbott's control over this family's community property, bought in 1940 is complete. He may at will give it away or sell it, mortgage it, or lease it for a long or short term without legal complaint by his wife, and should she predecease him she may not by will, dispose of any interest in this property.

Counsel might well have added that this situation existed in the face of the fact that for fifty-four years our statutory law has required the wife's written consent to gifts of commumity property, ${ }^{7}$ for forty-

r Statutes of 1891, p. 425, adding to original $\$ 172$ of CAx. Civ. Code the following proviso: "provided, however, that he cannot make a gift of such community property, or convey the same without a valuable consideration, unless the wife, in writing, consents thereto." Replaced in 1917 by first proviso in \$172 and first clause in \$172a which required wife "to join with her husband" in conveyances of realty rather than inerely to give her written consent thereto. 
four years has forbidden the husband to sell or encumber the household furnishings or wearing apparel of the wife and minor children without the written consent of the wife, ${ }^{8}$ for twenty-eight years has required the wife to join in any instrument by which community realty is sold, encumbered or leased for more than a year $;^{9}$ for over twenty years has stated unequivocally that the wife has testamentary power over one-half of the community property. ${ }^{10}$

Time marches on indeed, but Mrs. Abbott, so far as her com-. munity rights are concerned, still is living in the year 1890 !

2. The Barretts.

In the case of the Barretts, the following facts came to light. The Barretts had been married in 1908. Mrs. Barrett had been a court stenographer before her marriage, and had continued her work for ten years following her marriage. The nucleus of the property at issue had been purchased in 1916, and paid for by savings from the joint earnings of Mr. and Mrs. Barrett. In 1935, fronl the rentals derived from the original building of flats, the building was converted into an apartment house building which was exchanged for the ultimate property acquired in 1940.

Counsel informs the Barretts that Mr. Barrett, without his wife's written consent, could not lawfully encumber or sell the furniture or such of the wearing apparel of his wife and minor children as was community property; ${ }^{11}$ that he should have his wife's signature on

8 I.e., when such furnishings and wearing apparel are community property (Stat. of 1901, p. 598). Infra note 11.

$0 \$ 172$ a added by Statutes of 1917 , p. 829 , and reading, as to pertinent part, as follows: "The husband has the management and control of the community real property, but the wife must join with him in executing any instrument by which such conmunity real property or any interest therein is leased for a longer period than one year, or is sold, conveyed, or encumbered; . .."

10 Former Cal. Crv. Code $\S 1401$ as amended by Statutes of 1923, p. 30, reading: "Upon the death of either husband or wife, one-half of the commumity property belongs to the surviving spouse; the other half is subject to the testamentary disposition of the decedent, and in the absence thereof goes to the surviving spouse, subject to the provisions of section one thousand four hundred two of this code."

11 Just when the wearing apparel of the wife does not have the status of conmunity property may well be asked in the light of Estate of Walsh (1944) 66 Cal. App. 704, 52 P. (2d) 750, hearmg denied by supreme court. In that case the appellate court upheld the trial court's finding that jewelry and other feminine personal adornment which, the appellate court stated, had been proved to be delivered by the husband to the wife on Christmas, wedding anniversaries, etc., remained community property and did not become her separate estate, because there was no further proof that the husband intended a gift! 
any deed of gift should he desire to make a deed of gift of the property; and that in the absence of such signature his wife could file a suit to set aside the gift if she acted within a year of the date of recordation. ${ }^{12}$ Counsel informs Mr. Barrett that except for these limitations, his control over this community property and his freedom from testamentary interference by his wife should she predecease him, are as complete as those which were outlined above as possessed by Mr. Abbott.

Mrs. Barrett in respect to her marital property rights is living in the year 1916.

3. The Cabots.

This couple has been married only ten years. The legislature has not attempted to make any changes in the marital property law during the period which has elapsed since their acquisition of any of the funds which went into the purchase of their property.

Counsel informs them, therefore, that all the existing statutory provisions apply to their community property. $\mathrm{He}$ and his wife have present, existing and equal interests in the community estate. Mr. Cabot, however, is the legal manager of the community estate. Short of fraudulent disregard of his wife's interest therein, he may spend it, in general, according to his own judgment. He is, however, interdicted from either giving away the community personalty or disposing of the household furniture or the family paraphernalia without his wife's written consent. ${ }^{13}$ Mrs. Cabot is required to sign with him any instrument by which realty is conveyed (with or without consideration), is mortgaged or leased for more than a year. ${ }^{14}$

${ }^{12}$ Statutory period of one year after recordation added by Statutes of 1917, page 829, found in CAL. Crv. CoDE \$172a, and made applicable by this statute (and by the clarifying amendment of Statutes of 1927, p. 827) to all conveyances of realty in which the wife was required to join. (Including, of course, deeds of gift.)

13 If he violates this rule, however, title passes to the donee, and the wife must take steps to have the gift set aside in protection of her community property rights. See dictum, Spreckels v. Spreckels (1916) 172 Cal. 775, 782 et seq., 158 Pac. 537, 541, and subsequent cases following this dictum. Dargie v. Patterson (1917) $176 \mathrm{Cal}$. 714, $169 \mathrm{Pac}$. 360; Lehaney v. Lehaney (1929) 208 Cal. 323, 281 Pac. 67; Travelers Ins. Co. v. Fancher (1933) 219 Cal. 351, 26 P. (2d) 482; Trimble v. Trimble (1933) 219 Cal. 340, 26 P. (2d) 477. If suit is brought after the husband's death, the deed is set aside as to one-half only; if brought before the dissolution of the marriage by death (even if actually adjudicated later) the deed is set aside in its entirety. Britton v. Haunmel (1935) 4 Cal. (2d) 690, 52 P. (2d) 221.

${ }^{14}$ See Strong v. Strong (1943) $22 \mathrm{Cal}$. (2d) 540, $140 \mathrm{P}$. (2d) 386, for holding that her signature satisfies CAL. Crv. CoDE §172a, and that she need not be named as a cograntor. 
Mrs. Cabot may dispose by will of one-half of the community property, should she predecease her husband.

Thus, Mr. and Mrs. Cabot each have the marital property rights which represent the current legislative will unaffected by the past history of our marital property law.

It should be added, however, that the Cabots have not been freed from our doctrine of frozen rights. Assuming the continuance of the "prospective operation" rule, although their marital property rights now are fixed by contemporary law, five years hence that may no longer be the case. Should the legislature change our present control rules, the Cabots will jom the Barretts and the Abbotts in living with the discarded rules of the past, albeit a less remote past.

If this state of affairs existed because the legislature chose to have it that way, a constructive attack upon the situation by an adverse critic, would involve merely the expounding of its undesirability and a demand for legislative reform. History shows, however, that while the prospective application rule rests in a judicial sense upon legislative intent, (for the court has interpreted each of the enactments as applying only "prospectively") this "intent" has been construed into the statute in each case, because of the court's expressed belief that any other interpretation would be unconstitutional..$^{15}$

This is a matter of major importance. The Abbott, Barrett, Cabot situation, as a present phenomenon is one thing. As an inescapable "for all time" future situation impelled by the constitution, it is quite another.

It is commonly agreed by both bench and bar that our community property law in many respects is cumbersome, complicated and illadjusted to our needs. Except as a "taxsaver," it may be doubted that taking it all in all, it would be deemed a satisfactory marital property system by those who understand it. Yet by the constitutional theory which is challenged in the quotation that introduces these comments, and which has underlain our appellate decisions in the past fifty years,

15 Spreckels v. Spreckels (1897) 116 Cal. 339, 48 Pac. 228, interpreting the staute of 1891 which prohibited the husband from giving away community property without the wife's written consent. Roberts v. Wehmeyer (1923) $191 \mathrm{Cal} .601,218$ Pac. 22, interpreting the statute of 1917 which required the wife "to join with the husband in imstruments by which community real estate is sold, mortgaged, or leased for unore than a year." McKay v. Lauriston (1928) 204 Cal. 557, 269 Pac. 519, interpreting the enactment of 1923 which gave the wife the right to make testamentary disposition of one-half of the community property. 
we have not the right to scrap this system and replace it, or even to make changes by revisions which will be effective immediately. Indeed, carrying to its logical extreme ${ }^{10}$ this constitutional doctrine that "prospective" application is impelled, we may administer to our community property rules, other than those involving merely changes of succession, ${ }^{17}$ only the most protracted and lingering death.

As the suppositious cases which are posed above indicate, if this "prospective" rule is constitutionally required, then it follows that no old rule (i.e. one which antedates a projected change) can ever be fnlly deprived of force until the last married couple who are possessed of any community property prior to a projected change in inter vivos division or control, has had its union dissolved by death or divorce. ${ }^{18}$ By that time, the projected change may have been revised and so be, itself, in the process of gradual disappearance.

There was an intentional exclusion from the foregoing discussion, of any situation involving the effect upon the community property pattern of the 1927 change. The latter, for all practical purposes, we may accept as having provided, in respect to subsequent earnings of the spouses, ${ }^{19}$ for an equal sharing by husband and wife of the vested property right which had been held exclusively by the husband in previously existing community property. Whether each holds onehalf or whether both as in joint tenancy, are seized of the whole, or in some other fashion have equal interests, remains to be decided. ${ }^{20}$

${ }^{16}$ As to property acquired after 1927 , this logical extreme could be evaded by construing $\$ 161$ (a) to mean an adoption of the Wasbington doctrine expounded in Warburton v. White (1899) 176 U.S. 484 . Infra note 20 and notes $37-39$ and related text.

17 Supra note 4.

18 By agreement to bold the property under Civ. CoDE $\$ 161$ (a), it would seem clear the spouses could accelerate the process. On the right of the spouses to alter tbeir property relations by agreement, see Title Ins. Co. v. Ingersoll (1908) 153 Cal. 1, 94 Pac. 94 and cases cited therein.

19 We bave had no flat holding to date from our supreme court as to the exact result of CAE. CIv. CODE $\$ 161$ (a). It is not to be expected, however, that our court will come to any conclusion that will nullify the tax liability results of U.S. v. Malcolm (1931) 282 U.S. 792). That case certainly implies at least that the wife now shareg equally with the husband the vested interest in the commumity property.

20 The statute miglt even be construed as adopting the state of Washington theory expounded in Warburton v. White, supra note 16.

The adoption of this Washington theory could result, as to property acquired from 1927 on, in a determination that the control exercised by either husband or wife is a mere legislatively granted control unrelated to vested rights, and thus subject to changc at any time. It should be noted that the United States Supreme Court refused to express an opinion on this point so far as inter vivos control rules were concerned. 
The omission of the discussion of the effect of this 1927 change from the suppositious cases analyzed above was made for the purpose of separate reference to this particular statutory enactment.

Accepting the "prospective" constitutional theory, the result of the 1927 change is merely a compounding of legislative difflculties. The wife, as well as the husband, now has a vested right which the constitution protects from legislative interference. A two-edged, rather than a single-edged, sword, therefore, cuts at the effect of any future legislative enactment that makes a change in community property rules of inter vivos control. Should the legislature decide, for example, that it was a mistake to prohibit the husband, however large his community estate, from making any gift, however small, of community personalty without his wife's written consent, ${ }^{21}$ the application of the new rule to existing community property (or its rents, issues and profits) would, by thus cutting down the control previously enjoyed by the wife, impair the wife's vested property right.

In brief, under the expounded California constitutional doctrine, the legislature, before the 1927 change, when adopting a statute that imcreased the wife's control of community property (and thereby decreased that of the husband) could not make its application effective as to then existing community property, or property which was traceable to it, or to income from such property in all the years to come. Since 1927, under the logic of this same doctrine, the legislature in adoptimg a change that increases either the husband's or the wife's rights in community property has been similarly restricted, in respect to community property acquired after $1927 . .^{22}$ The legislature as to such property now can move in neither direction, for any change in control will run foul of the vested right of one of the spouses.

This state of legislative control, or rather lack of control over an important incident of the most fundamental social institution, the marital unit, has such cumbersome, inconvenient, and, it is submitted, undesirable results, as to justify a demand for clear proof of its constitutional necessity. Let us inquire into this necessity from the standpoint of both constitutional theory and decisions in point.

Looking first at state authority, we find that most of the litigation involving the application of legislative changes in marital property

21 Which is the rule imposed by our present Civil Code $\$ 172$.

22 "Acquired" after 1927 is used in the sense of not being traceable to community property owned before 1927. See supra note 5 . 
law arose over married women's property acts and the abolition of, or changes in, common law dower and curtesy. ${ }^{23}$ The cases which concerned statutes giving the wife control of her separate estate, and those which reviewed enactments which abolished common law dower and curtesy and substituted a definite share in fee in the estate left by the decedent spouse, are the most numerous.

In some of the cases which were adjudicated prior to 1888 , when by the case of Maynard $v$. Hill, ${ }^{24}$ it was settled that the marriage contract was not a contract within the constitutional prohibition against impairing the obligation of contracts, counsel maintained that dower and curtesy were part of the marriage contract itself, and that the rules im effect at the time of marriage therefore could not be altered constitutionally as to the marital partners. Certain of the courts agreed with this contention. ${ }^{25}$

In most of the cases, however, the issue raised was the familiar one of whether the dower or curtesy right in question was or was not vested. The earlier cases in the deference which they accorded the vested right, did not rest always upon the constitutional necessity of doing so, but rather upon the "general jurisprudential" principle ${ }^{20}$

${ }^{23}$ As only eight of our forty-eight states have community property systems, this inevitably would be the case.

24 (1888) 125 U.S. 210.

25 See e.g., brief of appellants in Randall v. Krieger (1874) 90 U.S. 137, at 145, wherein counsel in argumg against the propriety of applying a change in the rules for releasing a dower right to dower rights then existing, stated: "It is laid down in Lawrence v. Miller, and we thimk with abundant reason and authority, that the law of dower which existed at the time of marriage is the law of the contract which the husband and wife entered into by their marriage." See also an earlier New York case (Holmes v. Holmes (1848) 4 Barbour 295). The court held that a statute which gave the wife control of her separate estate would be void as unconstitutional in respect to existing estate in which the husband's rights were vested. It rested its conclusion both upon the due process clause of the New York constitution and upon the clause in the Federal Constitution which prohibits the impairment of obligations of contract. And in Lawrence v. Miller (N.X. 1849, 2 Comstock 245, at 250-252) a strong dictum declared that a change in marital property rules, which were in effect at the time of marriage would impair the obligations of a contract. See also Shuler v. Bull (1881) 15 S.C. 421, which holds that the marital property law is within the marital contract and so exempt from later change, because of the constitutional prohibition against impairing the obligation of contracts.

${ }^{26}$ See e.g., Davis v. O'Ferrall (Sup. Ct. of Iowa (1853) 4 G. Greenc 168 at 170):

"Every statute, which takes away or impairs a vested right, acquired under previous laws must be considered retrospective and opposed to those principles of jurisprudence which lave received universal commendation." See also e.g., Beale v. Knowles (1858) 45 Me. 479; Shyrock v. Cannon (1882) 39 Ark. 434; Booknight v. Epting (1878) 11 S.C. 71, offered no constitutional reasons for ruling against the apphication of the changed 
that a statute would not be given retrospective effect, if to do so would impair vested rights. The due process clause of state constitutions, however, was relied upon (even in some of the earlier cases) where the legislative intent to be retrospective was clear. On the advent of the Fourteenth Amendment to the Federal Constitution, the cases indicate the conceded unconstitutionality of inpairing a vested marital property right, ${ }^{2 \pi}$ and proceed to the issue of whether the right in question which is adversely affected by the statute under review is or is not a vested right.

The difference in opinion among the early writers in the field of dower, and among some of the earlier decisions and dicta as to the exact nature of the dower and curtesy rights, perhaps made the "vested" issue a natural one. For counsel who were defending the propriety of applying the change to all existing marital property, the strongest position was to deny the vested nature of the impaired rights. For counsel who were in opposition to such application, there was the traditional sanctity of property rights and the support of the opinion strongly held by such specialists in the field of dower as Scribner who maintained that even inchoate dower was a valuable property right which was entitled to constitutional protection. ${ }^{28}$

There is no evidence in most reports that argument was made in defense of the constitutional propriety of altering or replacing inchoate dower irrespective of its vested or non-vested character. As in our California cases concerning changes in the husband's control of community property, counsel seem to have rested their respective contentions on the nature of the property interest affected (i.e. whether vested or not) rather than raising the larger constitutional issue of the regulation of vested marital property rights in exercise of the

rule to existing property, but merely a flat statement that the contended for application would impair vested rights and so could not be allowed, and cf. the New York case of White v. White (1848) 5 Barbour 474, in which the court, after finding that the legislature clearly meant to give the wife control over existing separate property in which the husband also had vested rights and that such legislative action violated several clauses of the New York constitution, added that even were there no constitutional limitations on the legislature such legislative action would be beyond the legislative power because of the natural rights of the people who never had delegated to the legislature the power to take $A$ 's property and give it to $B$.

27 See e.g., Taylor v. Sample (1875) 51 Ind. 423, at 425 . "Vested rights inust be preserved as long as constitutional rights are respected."

$2 S 2$ SCRIBNER, THE LAW OF Dower, \$§ 13-18. However, despite his argument for the sanctity of inchoate dower, Scribner concedes earlier that it is not a vested estate in land. See ibid. p. 8. 
state's interest in the marital institution. By common consent, apparently, of contending counsel and court, the cases seem to have been disposed of by finding a change unconstitutional as to existing dower or curtesy, if deemed vested, and constitutional, if the other view was taken. The majority of jurisdictions entertained the view that inchoate dower was of a non-vested character and consequently vulnerable to legislative change while a minority took the other position. ${ }^{27}$ The positions were reversed in the attitude toward curtesy initiate..$^{30}$

The basic constitutional issue, while almost constantly overlooked, has not been quite universally ignored. Thus, the Oregon court in 1876, speaking through Mr. Justice Boise, held that a section . of the Oregon Constitution which cut down the husband's rights in his wife's separate estate applied equally to land already owned by married women as to land thereafter acquired. The court cogently argued: "... whatever interest W. C. Rugh, the husband acquired to this land, was derived through his marital rights in his wife's land. That interest at common law was the right to enjoy the rents and profits during their joint lives, and the right of curtesy (in case of

20 See the following cases in support of the view that inchoate dower was not a vested right and could be inpaired or abolished without running foul of tbe constitution: Ware v. Owens (1868) 42 Ala. 212; Noel v. Ewing (1857) 9 Ind. 37; Lucas v. Sawyer (1864) 17 Iowa 517; Barbour v. Barbour (1858) $45 \mathrm{Me}$. 9; Griswold v. Magee (1907) 102 Minn. 114, 112 N.W. 1020; Weaver v. Gregg (1856) 6 Ohio St. 547; Appeal of Melizett (1851) 17. Pa. St. 453; Bennett v. Harns (1881) 51 Wis. 251. In Illinois the first position taken by the court was that dower was vested although contingent. Russel v. Russel (1862) 35 Ill. 362. This view was overruled, however, in Henson v. Moore (1882) 104 Il. 409. Cf. Thornburg v. Thornburg (1881) $18 \mathrm{~W}$. Va. 522, construing an 1868 statute barring dower of wife who left husband without just cause.

For the contrary view, i.e. that inchoate dower may not be inpaired constitutionally see e.g. Williams v. Courtney (1883) 77 Mo. 587; In re Alexander (1894) 53 N. J. Eq. 96, 30 Atl. 817; and cf. Wheeler v. Kirtland (1875) 27 N. J. Eq. 534.

30 Estate of tenancy by courtesy initiate was generally held to be vested and therefore not affected by statutes enlarging the rights of married woinen in their property. See discussion in McNeer v. McNeer (1892) 142 III. 388, 32 N.E. 681; National Met. Bank v. Hitz (1881, Dist. of Col.) I Mackey 111. Similarly the husband's estate in the wife's personal property was held to vest on marriage and a later statute enlarging the separate property rights of married women was held not to be applicable constitutionally to such vested property. Buchanan v. Lee (1879) 69 Ind. 117, 121. The riglit of the husband to reduce his wife's choses in action to possession on the other hand was held by a majority of the cases not a vested right, prior to actual steps toward reduction, and so inpairable. Mellinger v. Bausinan (1863) $45 \mathrm{~Pa}$. St. 522; Alexander v. Alexander (1888) 85 Va. 353, 7 S.E. 335 ; Henry v. Dilly (1855) 25 N. J. L. 302. Some jurisdictions beld, however, that the right to reduce was a vested right and therefore protected from inpairment by the legislature. See e.g. Winn v. Riley (1899) 151 Mo. 61; O'Connor v. Harris (1879) 81 N.C. 271. Infra note 36. 
issue born alive) after her death. And on the marriage of plaintiff and W. C. Rugh, during our territorial government, the husband acquired the rights and profits of the land in Washington County, and such were the relations of plaintiff and her husband at the time of the adoption of our state constitution. ...

... It becomes therefore necessary to consider how far the real estate of women who were married at the time Oregon became a state was affected by section 5 , article 15 , of the state constitution. This section provides: 'The property and pecuniary rights of every married woman at the time of marriage or afterwards, acquired by gift, devise, or inheritance, shall not be subject to the debts or contracts of the husband.'

"It is claimed that this clause is only prospective, and applies only to future marriages, or property acquired after the establishment of the state government, and that it should not be construed so as to divest husbands then married of their marital rights in the real estate of their wives. The simple natural construction of the words used in this section, read by scholars unrestrained by legal technicalities or rules of construction of statutes, would include the property and pecuniary rights of married women who were then married and owning property which could be made subject to this provision. ... The plain meaning of the section is, that it applies in all its force to women then married, and protects their lands and their property from the debts and contracts of the husband, and such should be the construction given to it, unless we are compelled to restrain its full import to protect the marital rights of the husbands then married... .

"... the only reason that can be urged against such a construction is, that it modifies the marital rights of the husband in this land, to his injury, and, as in this case, may prevent creditors of the husband from selling the marital rights of the husband....

"It was by virtue of the marriage contract that the husband became at common law entitled to the use of his wife's land. ... If the section of the constitution under consideration, which changes the common-law rights of the husband, is right and proper in case of future marriages or of property acquired in future, it is also right and proper to apply it to the lands of persons then married, unless such a construction cannot be given it. Against such a construction it is claimed that the husband, by the common law, became on marriage invested with a freehold in the lands of the wife, which estate con- 
tinued for their joint lives. This estate, however, was conditional and subject to be defeated by a divorce $a$ vinculo. (Schouler's Domestic Relations, 300.) The marriage contract out of which this estate arose was at common law one in which the state was interested, and over which it exercised legislative control. It is both sui generis and publici juris....

"The marriage relation, affecting the whole public, and being an institution of society, affecting more deeply than any other the foundations of social order and public morals, has always been under the control of the legislature. The legislature can, and often does, dissolve the marriage relation between parties, and when the relation is thus destroyed the marital right to use the wife's land, which is incident to such relation, ceases longer to exist. And we think this right is not strictly a private right, but is one which is incident to a relation in which the whole community is interested. ..." ${ }^{\prime 1}$

A still more spirited attack upon the general view is found in the dissenting opinion rendered in a Kentucky case. ${ }^{32}$ This case had held the vested marital property rights of the husband could not be interfered with by a married women's property act which made a change in the marital property law. ${ }^{33}$ The dissent, after a careful analysis of the basic nature of the marriage contract and its sui generis quality, said: "The doctrine to be deduced from these cases is that the marriage status, or relation existing between husband and wife, is, with all its attendant rights, subject to the sovereign power of the state. The relation may be entirely abrogated, and every resultant right destroyed, together with the relation from which it sprung. This may be done upon proof being made of ground for divorce which occurred prior to the enactment of the law which made it such ground. This is upon the ground that the marriage relation and its attendant rights are'not included in the provision of the state or federal constitution as

31 (1876) 6 Ore. 231, 234-237.

32 Rose v. Rose (1898) 104 Ky. 48, 46 S.W. 524.

33 The majority opinion concluded: "Our conclusions are supported by the common law, by the consensus of judicial opinion, and by the ablest writers on constitutional law. We have thought it neither wise nor judicial to disregard the rules of law, which are the crystallization of judicial opinion. Neither do we think, because lawmakers may have been slow in giving to wives freedom in the control of their property, that we should give our sanction to a law which, if upheld, will take the property of the husband and give it to the wife. If change and transition are to take place in the domestic relntionship, although right and for the public good, still it should not be done at the sacrifice of vested rights." 
to laws impairing the obligation of contracts.... If the foundation of the rights may be taken away, with the result of the absolute destruction of such rights in all property which has not been lawfully consumed or disposed of during the existence of the marriage, why cannot the rights themselves be altered or modified or taken away without the dissolution of the marriage itself? What peculiar sanctity attaches to a marital right which does not belong to the institution of marriage? Does not the greater power include the less? Is not the whole greater than any of its parts?

"There are, it is true, a large number of cases, and numberless dicta, which either state or imply a distinction between the marriage status and the rights of property which accrue under it. ...

... It is conceded that, if we are to be guided by the mere number of cases which have been decided upon this question, the husband's contention must prevail. But if we are to reach our conclusion by reasoning from the nature of the marriage relation, and the principles which underlie it, it unust be decided in favor of the wife. . . My conclusion is that it was intended to take effect at once, as to all property held by virtue of existing or future marriages, except as to such as had been theretofore lawfully consumed or disposed of, and, further, that it is not in conflict with the constitution, for the reason that all rights obtained by virtue of the status of marriage are taken subject to the sovereign power of the state to alter and modify them...."

These protesting voices, however, are so occasional as to be clearly exceptional. State judicial authority apparently without even a struggle over the real constitutional question stands almost solidly on the theory that legislation must not be construed in such fashion as to impair vested marital property rights.

Turning to federal authority, several cases involving statutes which provided for the abolition or alteration of marital property rights have reached the United States Supreme Court. In the dower cases, the United States Supreme Court concluded that inchoate dower was not a vestẹd right ${ }^{34}$ and therefore could be dealt with by the law-making power as was deemed proper. The statements of the court in these cases in regard to the extensive legislative control over the incidents of the marital relationship obviously cannot serve as

34 See Randall v. Krieger (1874) 90 U.S. 137, 23 Wall. 13; Ferry v. Spokane, P. \& S. R. Co. (1921) 258 U.S. 314. 
authority for the constitutionality of changes which impair vested marital property rights.

The case of Baker's Executors v. Kilgore ${ }^{35}$ is of greater interest. This case was appealed from the highest court of Tennessee, and involved the constitutional propriety of exempting the profits from the wife's estate (which by Tennessee law as a result of tenancy by the marital right belonged to the husband as they accrued) from liability for the debts and contracts of the husband.

Challenging the judgment which had held that this statute applied to all rents and profits accruing thereafter, the husband's creditor contended this application infringed his vested rights. In affirming the judgment the Supreme Court not only stated that, before the profits accrued, the husband's right to them was a mere expectancy, but also added that the very right which he had, as husband, to take the profits from his wife's estate was one which rested "alone upon public considerations arising out of the marriage relation."

The court further stated: "... It was entirely competent for the legislature to change that rule in respect, at least, to the future rents and profits of the wife's estate. Such legislation is for the protection of the property of the wife, and neither impairs nor defeats any vested right of the husband. Marriage is a civil imstitution, a status, in reference to which Mr. Bishop has well said, 'public interests overshadow private- one which public policy holds specially in the hands of the law for the public good, and over which the law presides in a manner not known in the other departments.' I Bishop on Marriage, Divorce and Separation, \$5. The relation of husband and wife is, therefore, formed subject to the power of the State to control and regulate both that relation and the property rights directly connected with it, by such legislation as does not violate those fundamental principles which have been established for the protection of private and personal rights against illegal interference. ..."

This is a very mteresting dictum and the language reasonably can be read as indicating that the Supreme Court believed that all marital property rights, as between husband and wife, were subject to special regulation in the public interest, subject only to the limitation that other persons' vested rights should not be illegally disturbed.$^{30}$

35 (1891) 145 U.S. 487.

${ }^{36} \mathrm{Ibid}$. at 491 . The hushand's common law right in the realty of his wife, prior to hirth of issue, is descrihed by both Bishop and Kent as a freehold estate for their joint 
In the field of community property there have been two decisions of the United States Supreme Court which have passed upon the constitutional propriety of applying statutory changes in community property control to property in the possession of the spouses before such changes. The first of these, Warburton $v$. White, ${ }^{37}$ reviewed a decision of the State of Washington that concerned a statute passed in $1879^{3 \mathrm{~S}}$ which gave each of the spouses testamentary disposition as to one-half of the community property and provided for the passing of such one-half to decedent's issue in case of intestacy. The property in question in the case reviewed had been purchased in 1877, at which time neither spouse had any testamentary power, the whole community property going to the survivor on the death of either. Furthermore, by a statute which had been enacted in 1873, the husband had the entire management and control of community property in terms identical with those found in the original section 172 of our Civil Code $^{30}$ The holding by the Washington supreme court that the 1879 statute was effective as to this property (which had been purchased in 1877), and that as a result one-half of the community property descended to the child on the wife's death, was challenged as taking the husband's property without due process of law.

In affirming the Washington court's judgment, the United States Supreme Court pointed out that since the matter was essentially a domestic or state matter, it would follow the Washington court in its analysis of the vested interests involved in the Washington community property system. Quoting then from a number of Washington decisions, the Supreme Court concluded that under the Washington community property law:

(1) The husband and wife constituted together a compound creature of the statute called the marital community.

(2) The property interests of the husband and wife in this community were equal.

(3) This community owned the community property.

lives, liable to execution and subject to his conveyance. Bishop states that it is a vested estate which cannot be impaired constitutionally. See 2 KENT's COMMENTARIES, 130; 1 Bishop, Married WoMten, 529, 531; 2 ibid., \$40. See also Robertson v. Norris (1848) 11 Q.B. 916; Rose v. Rose, supra note 32.

37 (1899) 176 U.S. 484.

38 WASH. Ter. STaTS. 1879, p. 77.

39 "Entire management and control with hike absolute power of disposition as of his own separate estate." WASH. STATs. 1873, p. 450. 
(4) Community property could exist only when there was a marital community.

(5) When one of the spouses died, the marital community, so to spead, died, and the disposition of the decedent's interest was a mere problem of succession.

The Supreme Court refused to comment upon California's first Spreckels ${ }^{40}$ case, to which its attention had been called, doing so on the ground that it presented another question, i.e. that of inter vivos control, which was not pertinent to the question before the court. ${ }^{11}$ Clearly the case of Warburton $v$. White rests upon the particular community property theory expounded.

In the second case which reached the United States Supreme Court, Arnett v. Reade, ${ }^{42}$ the Court was called upon, in connection with a New Mexico community property statute, to decide a question definitely related to the issue presented in the Spreckels' case upon which the court had refused to comment in the case of Warburton $v$. White. The question in Arnett v. Reade concerned the constitutional limitations of a New Mexico statute enacted in 1901 which, like the amendment to our Civil Code (section 172a) enacted in 1917, prohibited the conveyance, mortgaging or encumbering of community real estate unless both husband and wife joined in the

\footnotetext{
40 (1897) 116 Cal. 339, 48 Pac. 228.
}

41 The court stated: "As the property in cquestion had not been sold by the busband, but on the contrary was held by him at the date of the death of the wife, no question is presented on this record of the nature and scope of his authority during the existence of the marriage, and we intimate no opimon on that subject.

"We have been cited to a decision of the Supreme Court of California, Spreckels v. Spreckels, 116 Cal. 339, construing an act somewhat similar to the Washington act of 1873 , which it is claimed is in conflict with the views enunciated by the courts of Washington in determining the proper construction of the statute of 1873 and the nature of an estate vested in a husband by virtue of that act. But the case referred to involved only the validity of the exercise by a husband, during the existence of a comnunity, of the power of dominion and control over the community property, and the right of the legislature to modify such authority and control with respect to prior acquired cominunity property. We are, therefore, unable to perceive the pertinency of that decision to the question arising for determination on this record, and we need not, therefore, review or consider it." Warburton v. White (1899) 176 U.S. 484, 497.

It must be remenbered, however, that the repeated emphatic statement of the opinion that the control powers vested in the husband were granted him purely in the capacity as agent for the marital community, indicate a conviction that the rules of inter vivos control were not frozen to those in existence at the acquisition of community property. Such has been the accepted view as to Washington community property.

42 (1911) 220 U.S. 311. 
execution of the instrument involved. The application of this statute to existing community property had been successfully challenged in New Mexico. The supreme court of that state had determined that it would impair vested rights of the husband if the legislature were allowed to apply the new rule to land previously acquired, and that such application would be unconstitutional, as violating the due process clause.

The United States Supreme Court, speaking through Mr. Justice Holnes (with one Justice dissenting) ${ }^{43}$ reversed the decision, giving a brief and not altogether lucid supporting opinion. ${ }^{44}$ The briefs of opposing counsel had made the familiar contentions in regard to what were the vested interests of the respective spouses in the community property, and the issue was clearly raised as to the husband's complete property right in the entire community estate.

The Supreme Court's opinion, while expressing definite skepticism of the soundness of the view (urged by respondent's counsel and supported by the decision of the New Mexico supreme court) that the wife had no real vested interest in the community property, does not finally resolve that issue. ${ }^{45}$ The decision actually goes no farther than to hold that whatever be the nature of the wife's interest in community property in New Mexico, at least "she has a greater interest than the mere possibility of an expectant heir" for "in one way or another she has a reinedy for an alienation made in fraud of her by her husband. ..." The opinion concludes, "As she was protected against fraud already, we can conceive no reason why the legislature

\footnotetext{
43 Mr. Justice McKenna who stated that he agreed with the Supreme Court of Arizona. He also referred to our first Spreckels case in support of his view.

44 Counsel for the wife maintamed in this case that the power of the husband in managing community property was merely that of an administrator or trustee and that it was not possession of a vested right in the actual property itself. Counsel contended, therefore, that to change or modify his power of control was not depriving him of a vested right. Counsel for the plaintiff, on the other hand, who fought to quiet title in community property which the husband had sold without his wife's participation in the conveyance, maintained that the marital property laws of the state were engraved on the marriage contract itself. (This contention the U.S. Supreme Court of course rejected in the authority of Maynard v. Hill (1888) 125 U.S. 190.) He also inaintained that the husband had the absolute and vested property right in the cominunity property during the subsistence of the community and that the wife had a inere expectancy in consequence of which it would be depriving the husband of his vested rights to permit the statute to apply to the property in question.

45 In a later Supreme Court case the contrary is stated. U.S. v. Robbims (1926) 269 U.S. $315,326$.
} 
could not make that protection more effectual by requiring her concurrence in her husband's deed of the land." 46

The opmion in this case is of special interest because it strongly suggests that a challenge of our court's constitutional theory would have been sympathetically received by the United States Supreme Court at this time. The reasoning upon which the court rested its reversal of the court below in this case, could have been used with equal propriety to describe our community property situation. Our supreme court had suggested from time to time that the wife had a more substantial expectancy than an ordinary heir and that she could have relief under our law from conveyances by the husband made in deliberate fraud of her rights. This viewpoint was expressly stated alreays to have been the law in the later famous test case of Stevort v. Stewart ${ }^{47}$ which, it will be remembered constituted the last major effort to force an admission from our supreme court that the wife's interest in the community property was of a vested nature. ${ }^{48}$

46 All these quotations are found on p. 320. (Arnett v. Reade (1911) 220 U.S. 311.) By way of dictum the opinion denies that as a result of Randall v. Krieger (1874) 90 U.S. 137 , it is settled that the wife's community property right could be abolished constitutionally by the legislature without cornpensation to the wife.

$4 \pi$ (1926) 199 Cal. 318, 249 Pac. 197.

48 The opinion of Stewart v. Stewart, stipra note 47, contains an exhaustive review of the California decisions in the community property field and the following paragraph nakes clear that the court is of the opinion that the nature of the wife's interest was in keeping with the above description. "We wish to say in conclusion that we are in accord with the intimations from tinue to time reflected by this court in the long line of its past decisions to the effect that the interest of the wife in the property of the community during the continuance of the marriage relation while it has not yet reached the status of a vested interest therein, is and has always been from a time reaching back into the Spanish and Mexican originals of our community property laws a nuch inore definite and present interest than is that of an ordinary heir. She has, by virtue of the share which in her own sphere she has contributed toward the acquisition and conservation of such properties, rights therein which have been always safeguarded against the fraudulent or inconsiderate acts of her husband with relation thereto and for the assertion and safeguarding of which she has been given access to appropriate judicial remedies both before and after the time when her said rights and interests would ripen and become vested through the death of the husband or other severance of the marriage relation whenever such rights and ultimate interests were affected by or threatened with such forms of invasion." 199 Cal. 318, 342, 343, 249 Pac. 197, 207, 208. Legislation was resorted to after the failure of the test cases culminating in this Stewart case in 1926. (There was a second appeal of this case decided in 1928, 204 Cal. 546, 269 Pac. 439.) Section 161a of the Civil Code was enacted in the following year, 1927.

"161a. The respective interests of the husband and wife in community property during continuance of the marriage relation are present, existing and equal interests under the management and control of the husband as is provided in sections 172 and $172 \mathrm{a}$ of 
It may be said in summary of the case of Arnett $v$. Reade, that as a decision of our highest court, it is of course authority of first importance. It seems clearly to indicate that the question of whether the marital property right affected is or is not vested is not the controlling or ultimate question in constitutional review. It also implies that such question is the usual constitutional test, namely: Is the statutory change a reasonably necessary and proper expression of the state's marital property policy? This, it is submitted, is sound constitutional doctrine. Constitutional history shows that it is not conclusive of the constitutional issue that a vested right is impaired by the application of a change in marital property law to existing community property.

Vested rights, of course, may be impaired "with due process of law" under many circumstances. The state's inherent sovereign power includes the so called "police power" right to interfere with vested property rights whenever reasonably necessary to the protection of the health, safety, morals, and general well being of the people. ${ }^{49}$ The annals of constitutional law are replete with decisions approving, as constitutionally proper, the impairing of, and even the complete confiscation of, property rights when compelling public interest justified it.

Thus, the state constitutionally may prohibit a man who owns ten thousand dollars worth of beer from selling it to certain persons, or at certain times, or even from selling it at all. ${ }^{50}$ It may, circumstances being sufficiently compelling, prohibit him in the same way from selling an automobile, a waterheater, or any other article unless he is presented by the purchaser with what is in effect the governinent's signature. ${ }^{51}$ In the interests of preservation of natural re-

the Civil Code. This section shall be construed as defining the respective interests and rights of husband and wife in the community property."

49 A more exact statement would be that the state's sovereign power is limited by the Fourteenth Amendment to the Constitution, i.e. property may not be taken "without due process of law." If legislation is (as found by the U.S. Supreme Court) reasonably necessary to the wellbeing of the people, then to the extent that it impairs property right, it does so "with due process of law." This is established constitutional doctrine.

50 Or even from continuing to have it in his possession. See e.g. Samuels v. McCurdy (1925) 267 U.S. 188, and cases cited therem.

51 The recent wartime regulations as to priorities and rationing under which the War Production Board and the Office of Price Administration operated are of course illustrations. For constitutional view of such price control and rationing, see Yakus v. United States (1944) 321 U.S. 414; Stewart v. Bowles (1944) 322 U.S. 398. 
sources $^{52}$ it may limit his use of his property, against his will. Similarly, by zoning ordinances and building "setback" rules it may limit his use of his property in the interest of general social comfort and convenience..$^{53}$ All this is commonplace.

The constitutional question, on principle, therefore, would seem to be, not whether a vested right is impaired by a marital property law change, but whether such a change reasonably. could be believed to be sufficiently necessary to the public welfare as to justify the impairment.

In answer to this question, it seems maintainable that compelling public policy considerations would support the legislature in making any change in marital property rules which could reasonably be expected to work an adjustment of the husband and wife's property interest which most spouses would approve as more satisfactory and more equitable than the previous rule. It should not matter whether such change added to the rights of the wife and subtracted from the rights of the husband, or vice versa, or worked such a complete change as to make it doubtful whether either was the practical net result.

The stability of the marital unit, while of course not dependent exclusively upon marital property rules, is not uninfluenced by them. So complete is the concern of the state in the preservation of its basic institution, especially perhaps in the face of the disintegrating forces to which modern conditions expose it, that there would seem to be no field of regulation that would be more obviously within the limits of legislative action than that of the marital institution and its incidents.

It might well be asked, in reference to this contention that the argument against the constitutional necessity of the "prospective operation" rule seems obvious, how it happens that such argument did not prevail in our courts.

As a matter of fact, a study of community property controversies of the last fifty years makes clear that the talents of our bar never were set to the task of presenting the constitutional justification of reshuffling marital property rights on the basis of the state's police power control of the marital relationship and its property incidents. Instead they were absorbed in the long drawn out battle which was

52 See e.g. Ohio Oil Co. v. Indiana (1900) 177 U.S. 190.

53 See e.g. Gorieb v. Fox (1927) 274 U.S. 603. See also Euclid v. Ambler Realty Co, (1926) 272 U.S. 364, and cf. discussion of these zoning cases in (1938) 27 CaLIF. L. REv. 52 . 
fought and lost to establish the fact that the husband did not have and never had had the exclusive vested property right in the community property, and that the wife always had had a true vested imterest therein. Counsel, who in the various cases were contending that a statutory control change should be effective for all existing community property as well as for community property acquired by future earnings, staked their all on their unsuccessful attempt to convince the courts that the husband had merely a legislatively granted business control ${ }^{54}$ of the community property which the legislature could diminish at will.

They argued that a mere change in this control of property vested in both husband and wife, would involve no impairment of a vested right of the husband. Since counsel thus denied that a deprivation ${ }^{55}$ of the husband's vested rights was inherent in any of the statutory changes in control, obviously they did not feel called upon to find constitutional justification for such non-existent deprivation. Instead, as frequently happens when counsel vigorously develops a selected line of argument, the unconstitutionality of applying any statutory change in control to existimg community property, assuming it to be true that such estate was vested in the husband, was actually conceded in the first major contest, i.e. in the case which construed the first statutory limitation on the husband's control of community property. ${ }^{60}$ It was reconceded or ${ }^{57}$ assumed in every succeeding case until the Thornton case. ${ }^{58}$

Thus in 1896, in an opening brief of appellant's counsel, in which

54 See notes 20 and 41 , supra.

E5 Mr. Chief Justice Beatty in the concurring opinion which he rendered in the first Spreckels case, expressed doubt that the 1891 statute (and similarly, it would follow, succeeding intrusions on the husband's right of control) involved a deprivation of the husband's vested rights. "It does not seem to me necessary, in order to sustain the ruling of the superior court upon this demurrer, to go to the extent of holding the proviso added to section 172 of the Civil Code by the act of 1891 an unconstitutional attempt to take away from the hushand his vested rights in community property acquired prior to that date. I am not at all clear that it does impair any vested right." $116 \mathrm{Cal} .339,350$.

Es Spreckels v. Spreckels (1897) $116 \mathrm{Cal}$. 339, 349, 48 Pac. 228, 235. See opening brief for appellants in the supreme court, S.F. 430 at p. 4.

57 Either completely or for argument purposes.

ES In this case which involved the constitutional propriety of converting marital property accuniulated in other states into the type of property it would have been if it had been accumulated in California, counsel argued that this conversion was proper even if it impaired vested rights. See supra note 66,68 , and 69 et seq. for further discussion. 
such counsel was supporting the propriety of applying the 1891 proviso $^{59}$ to community property which had been in the hands of the husband before the legislation was enacted, we find the following enlightening paragraphs: "It is elementary that a statute which undertakes to deprive a person of a right vested before its passage is unconstitutional. It is also unquestionable that, since property is the compound not only of the right to possess-the jus possidendi of the civilians-but, also, of the right to dispose-the $j u s$ disponendi-any statute which unreasonably interferes with one's vested right of disposing of one's property is unconstitutional. Equally clear is it that a legislative restriction upon the right to dispose of property which makes its exercise subject wholly to the will of a third party is unreasonable.

"When the claim is made that the Statute of 1891 is unconstitutional, in that it deprives the husband of a vested right, the argument assumes, as its foundation, that the husband had, before the passage of the Act, the vested right to dispose of community property by gift, as he might of his own separate property, and that, consequently, the enactment which makes his power of disposition subject to the consent of his wife, is a deprivation of that right.

"The answer to the contention is found in the fact that the husband never has had-no more before than since the passage of the Actthe power of disposing of the community property at his pleasure by gift, as he could of his separate estate; and that, besides, if he had such power, it was derived wholly from the Legislature, and the power which conferred it may take it away."

59 "Provided that he cannot make a gift of such community property or convey the same without a valuable consideration unless the wife in writing consents thereto." Amendment to CaL. Crv. CoDE $\$ 172$ added by Statutes of 1891, p. 425.

60 The argument continues, clearly indicating the line of attack taken in this case and in consequent cases involving a similar question. "The first Statute, passed in 1850, relatimg to the property rights of husband and wife, provides that 'the husband shall have the entire management and control of the common property, with the like absolute power of disposition as of his own separate estate.'

"Reading these words isolated from the considerations which properly surround them, they might, at first blush, seem to indicate that the husband held over community property the same dominion, both as to character and extent, that he did over his own separate property. Little reflection is needed, however, to demonstrate that, neither in character, nor extent, is the dominion the same. The right of management, control, and disposition which the husband has over his own separate property is the offspring of his ownership, partakes of its nature, and is inseparable from it. The alssolute owner of property has, so far as his relations to the property are concerned a right to deal with 
In its decision in this case, the supreme court takes the issue as presented to it by counsel for the appellant. Namely, "Is the entire property interest in commumity property vested in the husband?" decides that such is the case and that the amendment, in consequence, if applied to community property in his hands at the time that the amendment was enacted, would impair his vested right and so would be unconstitutional. Says the court: "The community property, as a rule, constitutes the earmings, gains, and savings of a man during his whole lifetime. If he can make presents to his friends, provide for indigent relatives, or make advancements to his children, it must be from this property. To deprive him of this power is certainly to divest him of a property right.

"The argument need not, however, be pursued further, because counsel admit that if the husband is the owner of the property, then a statute which makes the exercise of the right to dispose of it subject to the will of another is unconstitutional."

That is the sum of the holding, no more, no less. The all-important constitutional doctrine never was at issue. It was, by common consent, merely accepted.

Again, in the case of Roberts v. Wehmeyer, which denied the application to community estate already in the hands of the marital pair in question, of the 1917 amendment which requires the wife to "join with the husband in any instrument in which community real property is conveyed, mortgaged or leased for more than a year," counsel $^{62}$ in oral argument on behalf of such application clearly made an even more extensive concession in the following words: "Now, as a matter of fact, there is this question involved in Roberts v. Weh-

it as he pleases. He is the sole judge and master of his own conduct. He is accountable to no one. He can defraud no one. He wrongs no one but himself, even by his improvidence, extravagance, or caprice. The property is his alone. But, it is evident, that the husband's power of management, control, and disposition of the community property is, in origin, nature, and extent, very different from this. That power has its root, not in ownership, but in statute. The husband possesses it, not because he is the absolute owner of that property-for he is not-nor, from the fact that others have no concern in what is done with it-for they have-but, from the fact that the State has in its wisdom seen proper to confer it upon hin. He holds it by delegation from the State, not as owmer of the property, but as agent or trustee of the owner-the community, of which he is but a component part." Cf. supra note 41. Opening brief of appellant in Spreckels v. Spreckels, supra note 56.

01 Spreckels v. Spreckels (1897) 116 Cal. 339, 348-349, 48 Pac. 228, 231.

$62 \mathrm{Mr}$. Carey Van Fleet in oral argument on behalf of Mrs. Roberts. See Supreme Court Record, S. F. Civil No. 9652, Oral Argument of Mr. Van Fleet, at pp. 5, 6. 
meyer, that is, whether Section 172a of the Civil Code is constitutional or not. If, previous to its enactment in 1917, the husband was the absolute owner, with full and free power of disposal of the community proprty, if before 1917 the husband was as much the owner of the community property as he was of the separate property, there is some reason to the argunient that Section 172a of the Civil Code is unconstitutional, because it is imposing upon another person's property a limitation interfering with his free disposal and his absolute ownership, and it would not only be unconstitutional if construed retroactively, but it would be unconstitutional as construed prospectively. How can you get around that? If the legislature of the state gives a third person a right to say whether you can have your own property or not, it is unconstitutional, whether it is construed retroactively or prospectively. It is taking away property without due process of law."

Amici curiae in their briefs, on behalf of Mrs. Roberts, also emphatically stress this concession in their first point saying: ". . . If Section 172a is not unconstitutional, then it must be because it does not deprive the husband of any vested right. ... It follows also that if the title to the community property is in the husband, as maintained for so many years, then section $172 a$ of the Civil Code gives the wife the right of disposal over the husband's so-called title and this would seem to interfere with vested rights. ${ }^{63}$ The legislature cannot give one person the right to dispose of another person's property or to interfere therewith, even it would seem as concerns future acquired property as well as property accumulated before the provision went into effect...."

And again in the case construing the 1923 statute which granted the wife testamentary power over one-half of the community property, the Amici counsel who contended that this power extended to cominunity property accuniulated before 1923 rested on the same argument. The brief of such counsel maintains that the husband never had had the whole vested property right in the community estate; the wife as well as the husband in reality always had shared the vested property interest therein; the 1923 statute, therefore, was merely a succession statute and applied to all community property whether acquired before or after the 1923 amendment: ${ }^{64}$ It might be con-

63 Italics added.

64 Brief of Perry Evans, amicus curiae, supporting appellants in the supreme court, San Francisco, No. 12,691. This theory it will be remembered was held to describe the Washington community property system. 
tended that sub silentio at least, the Amici counsel also conceded that were the vested property right wholly in the husband and not at all in the wife, the application of the testamentary statute in question to property acquired before 1923 would be unconstitutional, for no answer was inade to the flat contention in the concluding statement of contending counsel's argument. This statement made in argument against construing the legislation as applicable to property acquired prior to 1923 concludes as to such construction: "... Such at attempt on the part of the Legislature is likewise quite apparently the taking of property without due process of law and, consequently, a violation of the Fourteenth Amendment to the United States Constitution, which provides 'nor shall any State deprive any person of life, liberty or property without due process of law.' ..." ${ }^{\prime 65}$

There is historical evidence that at least by the early thirties, our supreme court became aware that unsound constitutional doctrine had been relied on in our community decisions, and that it really carried on this doctrine on a "rule of property" basis. This seems implicit in the two supreme court decisions rendered in the Estate of Thornton in 1933 and 1934.

Probably there could be no better brief statement of the constitutional propriety of changing marital property rules than that which was expressed by the supreme court in the first opinion which it rendered in Estate of Thornton. ${ }^{66}$

It was in that history-nuaking case, it will be remembered, that the court finally negated the legislature's attempt, through Civil Code section 164 , to give to property ${ }^{67}$ which spouses domiciled here had acquired while living in a common law jurisdiction the marital property status which the property would have had, had it been acquired here under our community property rules.

Said the court in the first opinion it rendered: 68 "Even if . . that section does constitute a deprivation of a property right in the constitutional sense ... such legislation is permissible under the power

65 Brief of respondent in the supreme court, McKay v. Lauriston, San Francisco, No. 12,691 , at p. 5 .

66 (1933) 85 Cal. Dec. 253, 19 P. (2d) 778. Reheard and a contrary decision rendered in (1934) 1 Cal. (2d) 1,33 P. (2d) 1.

67 I.e., property subject to California's jurisdiction (realty in California and personalty wherever situated).

QS (1933) 85 Cal. Dec. 253, 260, 19 P. (2d) 778, 780. Italics added. 
of the legislature to control and regulate the marriage relation and its incidental property rights."

And in the opinion which it rendered after rehearing the case, in which it reversed its first holding that section 164 was effective, it seems suggested that the court had not changed its mind, and consequently its opinion on this particular aspect of the case, because it had ceased to believe in the constitutional theory that it had expressed in the above quoted paragraph. Rather, it had changed its opinion because section 164 accorded less protection in his marital property rights to the husband who accumulated his property elsewhere than, by a long line of decisions in California, we accorded to the husband who acquired community and separate property here. Such discriminatory treatment the court concluded could not be justified..$^{09}$

Said the court: "So long as we are bound by the holding that to limit the right of one spouse by increasing the right of the other in property acquired, by their united labors, is the disturbance of a vested right, we entertam no doubt of the application of at least two provisions of the Fourteenth Amendment to the Constitution of the United States. If the right of a husband, a citizen of California, as to his separate property, is a vested one and may not be impaired or taken by California law, then to disturb in the same manner the same

09 That this discrimination either would follow, or else a drastic change in a well established property rule would be called for, was persuasively argued in respondent's petition for rehearing, when counsel for respondent justifiably pointed out:

"This is also the first time that this Court has applied the power of the legislature to control and regulate the marriage relation and its incidental property rights, to the extent of authorizing the legislature to create a vested interest in one spouse in property in which such spouse therctofore had no interest at all; in support of which the Court cites Baker's Executors v. Kilgore, 145 U.S. 487. ... It is also apparent that if the doctrine of this case is to prevail as to the power of regulation of the marriage relation and its incidental property rights, even to the extent of taking away vested rights, which is the purport of the opimion herein, then the community doctrine in California is again thrown into confusion, and the case of Spreckels v. Spreckels, stupra, and the long line of cases following have been wrongly decided. Either that, or this Court has made a distinction between the regulation of the marriage relation and marital rights between citizens coming from other states and citizens who are citizens of this state, ... It will be seen, therefore, that this is a record-making decision, upsetting titles and doing away with what has been declared continually to be a rule of property with regard to the commumity system in this state."

Petition submitted by Carey Van Fleet, Attorney for Contestants and Respondents; Treadwell, Van Fleet \& Laughhin, Attorneys for Contestants and Respondents, Lucy Creswell, H. I. T. Creswell and Gertrude Creswell. Pillsbury, Madison \& Sutro, Maurice D. L. Fuller, Attorneys for Contestant and Respondent, The Bank of California, National Association. 
property right of a citizen of another state, who chances to transfer his domicile to this state, bringing his property with him, is clearly to abridge the privileges and immunities of the citizen. ..."70

In brief, the court felt bound by the often repeated holding that the control of rights in both commumity ${ }^{71}$ and separate property of spouses who acquired this property while domiciled here, remained untouched by subsequent statutory changes in such control. The court felt, therefore, that it could not support legislation that reached a contrary conclusion as to property brought into this state after being accumulated in a common law state.

Moreover, it is understandable that the court, however emphatically it may have subscribed to its previously expressed constitutional doctrine, should feel dismclined after sober reflection to face, in a case which concerned only the effect of a statute regulating the marital property rights of those who brought property into this state, the much larger problem of the soundness of constitutional doctrine which underlay a line of decisions that fixed the marital property rights of the spouses who accumulated their property while domiciled in California. It would seem clear that such an issue should be considered under conditions which would permit the fullest possible argument with opportunity for briefs and arguments of amici representing all points of view and all interests involved.

It might be queried whether the abandonment of the constitutional doctrine of "prospective" necessity in making changes in marital control would not involve an unacceptable jolt or shock to the established law of our state. Appraisal of the actual decisions, however, would seem to yield the conclusion that this would not be the case.

In the exact sense of "decision" prevalent in the days of earlier and perhaps more orderly legal usage it could be said, that since the adoption of the codes in the early seventies, there never has been a flat decision on constitutionality in respect to changes in marital property law except in the Thornton case. ${ }^{i 2}$ That is so, for the reason that there has never been a decision which could have rested only upon the principle that the change in control of community property which

To (1934) I Cal. (2d) 1, at 5, 33 P. (2d) 1, at 3. (Italics added.)

11 This included the rents, issues and profits of said property. See Boyd v. Oser (1944) 23 Cal. (2d) 613, 145 P. (2d) 312.

72 (1934) 1 Cal. (2d) 1, 33 P. (2d) 1, discussed supra. 
had been made by the statute under consideration, constitutionally was inapplicable to existing community property. Putting it another way, the decisions which settled the meaming of each of the successive changes while offering constitutional necessity as the supporting reason for the extreme "prospective" operation construction which it applied, could rest securely upon the basis of mere construction of legislative intent. The legislature in no case presented wording which was inescapably retrospective, and after a "prospective operation" construction by the courts, the legislature in no case altered the language of the ineasure to make it read retrospectively and so force a facing of the constitutional issue, as it forced the constitutional issue in amending Civil Code section 164, which was ultimately disposed of in the previously discussed Thornton case.

Furthermore, as has been made clear, the case which brought this constitutional doctrine into our law did not really have the constitutional question before it as an issue. Counsel on the one side contended, counsel on the other side agreed and conceded. Subsequent cases in the main followed the same pattern. ${ }^{73}$

The place of any doctrine that rests ultimately on concession of counsel rather than adjudication of a litigated issue, is never one of high honor and the expunging of such doctrine from the law is not a shocking process.

In summary it may be said that there would seem to be no more satisfying description of the situation in which we find ourselves with reference to the "prospective" operation rule than that which was expounded in the introductory quotation paragraph. We have developed a rule of property that the legislative enactments of 1891, 1901, 1917 and 1923 which put limitations upon the husband's control of community property and gave to the wife certain control powers have no application to property which is traceable either to community property possessed ${ }^{74}$ at the time of the change in question or to rents, issues and profits of such community property.

The original reasons for adopting a rule are of course immaterial when by long usage and continued judicial sanction, it has become a rule of property. The rule of property receives legal respect by virtue of a species of public estoppel, i.e. because of long established dealings in reliance upon it. Under no circumstances, however, does

73 See supra notes 56 and 65 and pertinent text.

74 See supra note 5 . 
the legal respect which is held to be due to the rule of property carry over to the reasons for its adoption in the first place. Indeed, it is because the foundation for the rule in question has slipped away (or never really had been there) that it needs to be recognized as a rule of property.

It follows, therefore, that although unsound constitutional doctrine caused the interpretation of "prospective" application in the case of statutes which changed community property control rules, this interpretation in deference to long usage has become a rule of property. We are bound, therefore, not to reinterpret these statutes to coincide with what sound constitutional theory would have found them to mean in the first place. But that is as far as we are bound and as far as deference is due. We will not assume that future legislatures under no circumstances may make legislative changes in the coinmunity property law which impair the vested property rights of either or both of the marital partners. Instead we will, as to such possible future legislation, return to the constitutional theory expressed in the first Thornton case decision. We will examine any such future community property legislation im the light of inodern conceptions of the constitutional limits of the state's legislative power.

The inarital unit is still the foundation stone of society. The firmness of that foundation is of primary importance. Economic aspects of the marital partnership inevitably affect it. A marital property system that is uncomplicated, understandable, and as nearly as possible in tune with contemporary conviction is of constant concern to us all. A rejection of the unfortunate constitutional doctrine which has found its way into community property decisions will not bring us this desired property law. It will, however, unshackle the legislature and thus put the system within our statutory reach.

An early adoption by the Suprenie Court of the special concurrmg opinion rendered in Boyd v. Oser ${ }^{75}$ would seem both logical and desirable. 